\title{
Poor oral health may prolong COVID-19 illness
}

\author{
Shipra Gupta ${ }^{1}$, Timo Sorsa ${ }^{2}$, Ella Brandt ${ }^{2}$, Ismo T. Räisänen ${ }^{2 *}$ (0), Ritin Mohindra ${ }^{3}$ and Kapil Goyal ${ }^{4}$
}

\section{Letter to Editor,}

We applaud the efforts of Wang et al. 2021 for their Mendelian randomization study on how periodontal disease increases the host susceptibility to COVID-19 along with its severity, published in Journal of Translational Medicine [1]. They report on the basis of genetic evidence, significant association of Periodontal disease with susceptibility to COVID-19 and its severity based on comparison of hospitalization versus population controls. We agree with the authors of the study that periodontal disease is a modifiable factor, and rigorous oral hygiene maintenance could go a long way in reducing the predisposition to COVID-19 related adverse complications.

Since the start of the pandemic in 2019, our team has been working diligently towards unravelling the intricacies of this association [2-6]. An association between periodontitis and higher risk of Intensive Care Unit admission, need for ventilation and death of COVID-19 patients, is now well documented [3]. Furthermore, data collected by us suggests that periodontitis may also prolong the number of days of COVID-19 illness (Fig. 1). Periodontally healthy patients had on average 4.15 days of illness (95\% confidence interval: 3.18-5.12), patients with gingivitis 5.76 days ( $95 \%$ CI: 3.93-7.59) and patients with periodontitis 7.37 days (95\% CI: 5.48-9.25). Thus, good oral health seems very much beneficial not only in the prevention of COVID-19 related adverse outcomes,

This comment refers to the article available online at https://doi.org/10.1186/ s12967-021-03198-2

${ }^{*}$ Correspondence: ismo.raisanen@helsinki.fi

2 Department of Oral and Maxillofacial Diseases, University of Helsinki and Helsinki University Hospital, Helsinki, Finland

Full list of author information is available at the end of the article but also in potentially shortening the duration of the disease. It could help reduce the economic burden on the individual and the society at large by cutting down on the number of days the patients stay away from work. Hence any diagnostic modality which could predictably screen the presence of periodontal disease could very well act as an alarm to encourage and motivate the patients to seek dental care before it has progressed to severe stage. Recently developed and validated active matrix metalloproteinase (aMMP)-8 point-of-care/chair-side biomarker technology provides possibilities for health care professionals in this regard [6]. These lateral flow immunoassay based kits are capable of diagnosing active periodontal disease at both full-mouth and site-specific levels and can aid in tailoring therapy as per patient requirements and at the same time sensitizing them towards the need to maintain oral health [6].

These kind of preventive oral health strategies could aid in concentrating health care resources more efficiently on helping risk patients with additional comorbidities to have a better oral health and protection against infections caused by microbial pathogens, such as bacteria and viruses, and possibly reducing the risk of superinfections reported among severe COVID-19 cases. At the same time, it could also help to increase individuals' knowledge of their possible periodontal disease and its current state and effects, which they often are unaware, and make it easier to motivate patients toward better oral hygiene and oral health. The selective identification and protection of these people at-risk individuals could be a costeffective way of disease management, especially in areas with limited medical/dental facilities. Thus, this targeted prevention strategy could increase the general level of public health as well.

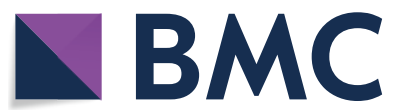

(c) The Author(s) 2022. Open Access This article is licensed under a Creative Commons Attribution 4.0 International License, which permits use, sharing, adaptation, distribution and reproduction in any medium or format, as long as you give appropriate credit to the original author(s) and the source, provide a link to the Creative Commons licence, and indicate if changes were made. The images or other third party material in this article are included in the article's Creative Commons licence, unless indicated otherwise in a credit line to the material. If material is not included in the article's Creative Commons licence and your intended use is not permitted by statutory regulation or exceeds the permitted use, you will need to obtain permission directly from the copyright holder. To view a copy of this licence, visit http://creativecommons.org/licenses/by/4.0/. The Creative Commons Public Domain Dedication waiver (http://creativeco mmons.org/publicdomain/zero/1.0/) applies to the data made available in this article, unless otherwise stated in a credit line to the data. 


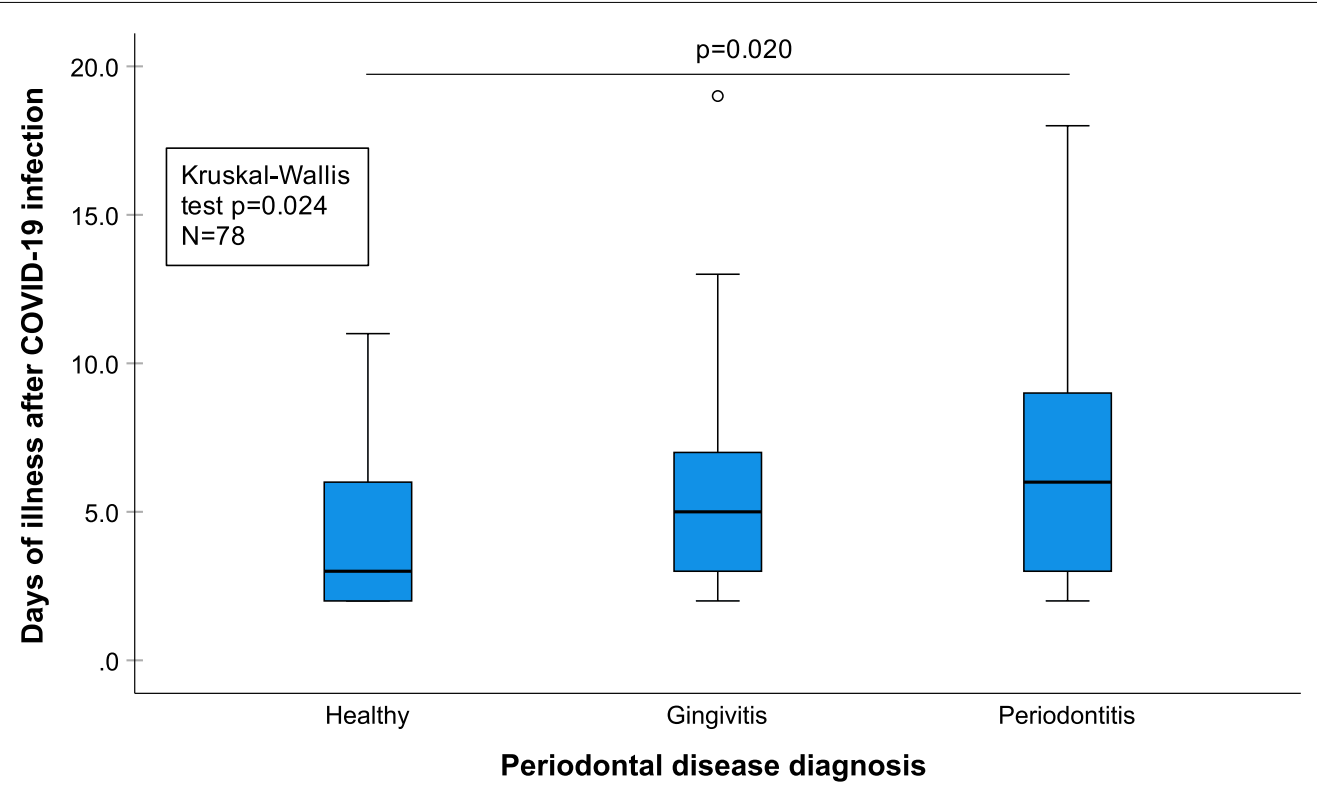

Fig. 1 Periodontal disease diagnosis versus days of illness after COVID-19

\section{Acknowledgements}

Professor Timo Sorsa is the inventor of U.S. patents 1,274,416, 5,652,223, $5,736,341,5,864,632,6,143,476$ and US 2017/0023571A1 (issued June 6 , 2019), WO 2018/060553 A1 (issued May 31, 2018), 10,488,415 B2, and US 2017/0023671 A1, Japanese Patent 2016-554676 and South Korean Patent No. 10-2016-7025378. Other authors report no conflicts of interest related to this study. The funders had no role in the design of the study; in the collection, analyses, or interpretation of data; in the writing of the manuscript, or in the decision to publish the results.

\section{Authors' contributions}

SG contributed to conceptualisation, data curation and writing-original draft. EB and IR did the formal analysis, validation and writing-review \& editing. TS supervised the study along with writing-review \& editing. RM and KG contributed to data curation and writing-review \& editing. SG and IR have directly accessed and verified the data reported in the manuscript. All authors read and approved the final manuscript.

\section{Funding}

Professor Timo Sorsa received financial support for this study from the Finnish Dental Society Apollonia, Finland; the Karolinska Institutet, Stockholm, Sweden; the Helsinki and Uusimaa Hospital District (HUS), Grant/Award Numbers:Y1014SULE1, Y1014SL018, Y1014SL017, TYH2019319, TYH2018229, TYH2017251, TYH2016251, TYH2022225. Other authors received no financial support for the research, authorship, and/or publication of this article. This work was carried out as a part of routine COVID-19 diagnostic activity of the Regional Virus Diagnostic Laboratory under ICMR New Delhi, by the Department of Virology, PGIMER, Chandigarh.

\section{Availability of data and materials}

Data and material can be achieved by email to the corresponding author (E-mail address: ismo.raisanen@helsinki.fi).

\section{Declarations}

\section{Ethics approval and consent to participate}

Due approval was taken from Institutional Ethics Committee, Postgraduate Institute of Medical Education and Research, Chandigarh, India (INT/IEC/2021/ SPL-636). All participants signed informed consent.

\section{Consent for publication}

All authors read and consented the final manuscript for publication.

\section{Competing interests}

The authors declare that they have no competing interests.

\section{Author details}

${ }^{1}$ Unit of Periodontics, Oral Health Sciences Centre, Post Graduate Institute of Medical Education \& Research, Chandigarh, India. ${ }^{2}$ Department of Oral and Maxillofacial Diseases, University of Helsinki and Helsinki University Hospital, Helsinki, Finland. ${ }^{3}$ Department of Internal Medicine, Post Graduate Institute of Medical Education \& Research, Chandigarh, India. ${ }^{4}$ Department of Virology, Post Graduate Institute of Medical Education \& Research, Chandigarh, India.

Received: 10 February 2022 Accepted: 14 February 2022

Published online: 07 March 2022

\section{References}

1. Wang Y, Deng H, Pan Y, Jin L, Hu R, Lu Y, Deng W, Sun W, Chen C, Shen X, Huang XF. Periodontal disease increases the host susceptibility to COVID19 and its severity: a Mendelian randomization study. J Transl Med. 2021;19(1):1-9.

2. Gupta S, Mohindra R, Chauhan PK, Singla V, Goyal K, Sahni V, Gaur R, Verma DK, Ghosh A, Soni RK, Suri V, Bhalla A, Singh MP. SARS-CoV-2 detection in gingival crevicular fluid. J Dent Res. 2021;100(2):187-93. https:// doi.org/10.1177/0022034520970536.

3. Gupta S, Mohindra R, Singla M, Khera S, Sahni V, Kanta P, Soni RK, Kumar A, Gauba K, Goyal K, Gupta S, Mohindra R, Singla M, Khera S, Sahni V, Kanta P, Soni RK, Kumar A, Gauba K, Goyal K, Singh MP, Ghosh A, Kajal K, Mahajan V, Bhalla A, Sorsa T, Räisänen I. The clinical association between Periodontitis and COVID-19. Clin Oral Investig. 2022;26(2):1361-74. https://doi.org/ 10.1007/s00784-021-04111-3.

4. Gupta S, Mohindra R, Jain A, Singla M, Sorsa T, Räisänen I, Malhotra M, Soni RK, Kumar A, Kanta P, Gauba K, Singh MP, Ghosh A, Suri V. Toothbrush as a sampling methodology for detection of SARS-CoV-2. Oral Dis. 2021. https://doi.org/10.1111/odi.14122. 
5. Sahni V, Gupta S. COVID-19 \& periodontitis: the cytokine connection. Med Hypotheses. 2020;144: 109908. https://doi.org/10.1016/j.mehy.2020. 109908.

6. Sorsa T, Sahni V, Buduneli N, Gupta S, Räisänen IT, Golub LM, Lee HM, Pätilä T, Bostanci N, Meurman J, Pärnänen P, Nwhator SO, Singla M, Gauba K. Active matrix metalloproteinase-8 (aMMP-8) point-of-care test (POCT) in the COVID-19 pandemic. Expert Rev Proteomics. 2021;18(8):707-17. https://doi.org/10.1080/14789450.2021.1976151.

\section{Publisher's Note}

Springer Nature remains neutral with regard to jurisdictional claims in published maps and institutional affiliations.

- fast, convenient online submission

- thorough peer review by experienced researchers in your field

- rapid publication on acceptance

- support for research data, including large and complex data types

- gold Open Access which fosters wider collaboration and increased citations

- maximum visibility for your research: over $100 \mathrm{M}$ website views per year

At $\mathrm{BMC}$, research is always in progress.

Learn more biomedcentral.com/submissions 